\title{
Reaction of Aromatic Azides with Strong Acids: Formation of Fused Nitrogen Heterocycles and Arylamines
}

\author{
Marcia de Carvalho, Ana E.P.M. Sorrilha, and J. Augusto R. Rodrigues*
}

\author{
Instituto de Química, Universidade Estadual de Campinas,
} 13083-970 Campinas - SP, Brazil

\begin{abstract}
Descrevemos neste trabalho a ação de ácido trifluoroacético, ácido trifluorometanossulfônico e cloreto de alumínio sobre aril azidas orto-substituídas para formar indóis, azepinas e arilaminas com bons rendimentos. As azidas protonadas perdem nitrogênio para formar íons arilnitrênios intermediários que sofrem $\mathrm{N}$-substituição aromática intramolecular. A decomposição ácida de aril azidas é comparada com resultados de termólise tomados da literatura.

We describe in this paper the action of trifluoroacetic acid, trifluoromethanesulfonic acid and aluminum chloride upon ortho-substituted aryl azides to form indoles, azepines and arylamines in good yields. The protonated azides lose nitrogen to form arylnitrenium ion intermediates which undergo intramolecular aromatic $\mathrm{N}$-substitution. The acid decomposition of aryl azides is compared with reported thermolyses.
\end{abstract}

Keywords: nitrenium ion, aryl azides, indoles, azepines

\section{Introduction}

Nitrenium ions are reactive intermediates that have been the subject of much recent attention ${ }^{1}$. One reason for this is the proposal that arylnitrenium ions are intermediates in the reactions whereby various chemical carcinogens damage $\mathrm{DNA}^{2}$. The target of this reaction appears to be guanine bases in the DNA molecule ${ }^{3}$. Studies have confirmed that arylnitrenium ions, alleged to be involved in the carcinogenic pathways, do in fact react very rapidly with the critical DNA components ${ }^{4}$. Moreover, it has become increasingly clear that various ions have microsecond or longer lifetimes in water ${ }^{5}$.

Intramolecular remote functionalization by arylnitrenium ions ${ }^{7}$ is an useful method for forming $\operatorname{six}^{-{ }^{7 a}}$ and seven-membered rings ${ }^{7 \mathrm{~b}}$, lactones ${ }^{7 \mathrm{a}-\mathrm{c}}$, dihydroxepines ${ }^{7 \mathrm{~d}}$, dihydrophenanthridines and benzo[c]chromans ${ }^{7 e}$. There are few examples in the literature which describe the intramolecular electrophilic attack by a nitrenium ion upon an ortho-aromatic nucleus. The reaction of boron trichloride with an ortho-aryl and ortho-diazoaryl phenyl azides at room temperature yielded fused azoles via 1,5-cycliza$\operatorname{tion}^{8 \mathrm{a}, \mathrm{b}}$. Cyclization of 4-azido-3-phenyl-3-phenylpyridazines and 7-azido-6-phenyltetrazolo[ $1,5-b]$ by heating with strong acids like methanesulfonic acid gave $5 \mathrm{H}$-pyridazino[4,3- $b$ ] indoles and $10 \mathrm{H}$-tetrazolo[1',5':1,6]pyridazino $[4,3-b]$ indoles, respectively ${ }^{8 c}$. A remarkable formation of a sixteen-membered ring by an intramolecular electrophilic aromatic substitution involving a nitrenium ion was reported by Abramovitch and coworkers ${ }^{8 \mathrm{~d}}$. The decomposition of 1-(3-azidobenzyl)-5,6-dimethoxy-2-methyl1,2,3,4-tetrahydroisoquinoline in TFA/TFMSA at $-5{ }^{\circ} \mathrm{C}$ was observed to afford pronuciferine in 5\% yield together with uncyclised amine (16\%) [precursor to starting azide] resulting from hydrogen abstraction by the reactive intermediate. Using the same acids, Takeuchi reported that aryl azides undergo intermolecular aromatic $\mathrm{N}$-substitution ${ }^{9 \mathrm{a}-\mathrm{c}}$. Inter- and intra-molecular aromatic $\mathrm{N}$-substitution by arylnitrenium-aluminium chloride complexes generated from aryl azides in the presence of aluminium chloride was reported by Takeuchi ${ }^{10}$. Olah et al. studied triflic acid catalyzed phenylamination of aromatics with phenyl azide and they propose two alternative intermediates, a phenylaminodiazonium ion or phenylnitrenium ion ${ }^{11}$.

In this paper, we report the reaction of various orthosubstituted aryl azides with strong acids like trifluoroacetic acid, trifluoromethanesulfonic acid and aluminum chloride to form nitrenium ion intermediates that collapse to a nitrogen five and seven-membered ring. Also we compare these results with thermal decomposition of the same azides in which a nitrene is the reactive intermediate. 


\section{Results and Discussion}

trans-2-Azidostilbene 1, prepared by the procedure of Sundberg ${ }^{12}$, was treated in dichloromethane at $0{ }^{\circ} \mathrm{C}$ with trifluoromethanesulfonic acid (triflic acid) or trifluoroacetic acid. The temperature was allowed to reach the ambient and after neutralization, the crude material was purified by thick layer chromatography on silica gel to give 2-phenyl- $1 H$-indole 3, mp $187-188^{\circ} \mathrm{C}^{13}$, in $85 \%$ yield. This cyclization suggests that protonated azide, a nitrenium like ion or a nitrenium ion, resulting from the protonated azide by loss of nitrogen ${ }^{7 a, 9 a}$, is responsible for the formation of the five membered ring (Scheme 1). Since Takeuchi reported formation of arylnitrenium ion (or a nitrenium- $\mathrm{AlCl}_{3}$ complex) from decomposition of azides in presence of $\mathrm{AlCl}_{3}$, we treated 1 under the same conditions ${ }^{9 \mathrm{c}}$. After the evolution of nitrogen stopped, the excess $\mathrm{AlCl}_{3}$ was destroyed by $10 \% \mathrm{NaOH}$ and after purification on silica gel plates, we isolated trans-2-aminostilbene, mp 101$103{ }^{\circ} \mathrm{C}^{13}$, (formed by triplet nitrenium ion hydrogen atom abstraction) in $45 \%$ yield and only traces of $\mathbf{3}$. Thermolysis of 1 in ethylene glycol (reflux for $4 \mathrm{~h}$ ) also furnished the 2-phenyl- $1 \mathrm{H}$-indole in $87 \%$ yield but in this case the intermediate is a nitrene ${ }^{12}$. Decomposition of $\mathbf{1}$, either in acidic conditions or by thermolysis, gave 2 -phenyl- $1 H$-indole $\mathbf{3}$ with comparable yields.

A solution of ethyl 3-(2-azidophenyl)propenoate 2 (prepared from ethyl propenoate 5) in dichloromethane when treated with triflic acid at $0{ }^{\circ} \mathrm{C}$ gave ethyl $1 H$-indole-2-carboxylate 4 (m.p $\left.124-125^{\circ} \mathrm{C}\right)^{14}$ in $38 \%$ yield, ethyl $E-3-(2-$ aminophenyl)propenoate (pale yellow needles, m.p. 77-78 $\left.{ }^{\circ} \mathrm{C}\right)^{24} \mathbf{5}$ in $17 \%$ yield, ethyl 3-(5-trifluoromethanesulphonate-2-aminophenyl)propenoate $6, \mathrm{mp} 85-86^{\circ} \mathrm{C}$, in $5 \%$ yield and traces of ethyl 3-(3-trifluoromethanesulphonate-2-aminophenyl) propenoate. The decomposition of $\mathbf{2}$ in TFA under the same conditions gave the indole 4 in $49 \%$ yield and $\mathbf{5}$ in $22 \%$ yield. Thermolytic decomposition of azide $\mathbf{2}$ in xylene reflux overnight gave $1 H$-indole-2-carboxylate 4 in $75 \%$ yield. The nitrenium intermediate generated from 2 in acidic medium can be intercepted either inter- or intramolecularly (giving 4, 5 and 6 with a reasonable total yield) but the nitrene intermediate formed by thermal decomposition of $\mathbf{2}$ gave only the intramolecular product, the $1 \mathrm{H}$-indole $\mathbf{4}$ in good yield. The inferior yield of $\mathbf{4}$ with the acid catalyzed reaction in relation with $\mathbf{3}$ may be a consequence of the more electrophilic character of the double bond in the cinnamate in comparison to the stilbene.

Ethyl E-2-azido-3-phenylpropenoate 7 (prepared by the<smiles>CCOC(=O)c1cc2ccccc2[nH]1</smiles>

procedure of Hermtsberger ${ }^{15}$ with the Rees modification ${ }^{16}$ ) with triflic acid in dicloromethane at $0{ }^{\circ} \mathrm{C}$ gave the $1 \mathrm{H}$-indole 4 in $45 \%$ yield, mp $124-125{ }^{\circ} \mathrm{C}$, while the TFA-catalyzed reaction under the same conditions gave 4 in $52 \%$ yield. Decomposition with $\mathrm{AlCl}_{3}$ gave the $1 H$-indole 4 in $29 \%$ yield. Both reactions gave tarry material from which the $1 H$-indole 4 was isolated with difficulty. Thermolysis of $\mathbf{7}$ in xylene was reported to give $\mathbf{4}$ in high yield via a nitrene intermediate ${ }^{17}$ and again this procedure gave a superior yield to the acid decomposition.

cis-2-Azidostilbene $\mathbf{8}$ was prepared by the procedure of Staub $^{18 \mathrm{a}}$ with the modifications of Detar and $\mathrm{Chu}^{18 \mathrm{~b}}$ as an oil with IR and NMR identical to those reported by Smith et al. ${ }^{19}$ Decomposition of $\mathbf{8}$ in dichloromethane solution with triflic acid gave $5 H$-dibenz[b,f]azepine 10, mp 198 $199{ }^{\circ} \mathrm{C}^{20}$, in $58 \%$ yield together with cis-2-aminostilbene 12, mp 63-64 ${ }^{\circ} \mathrm{C}^{17 \mathrm{~b}}$, formed by reduction of the intermediate arylnitrenium in $17 \%$ yield. Very similar results were obtained with TFA, 10 was formed in $62 \%$ yield and $\mathbf{1 2}$ in $19 \%$ yield. Since Smith ${ }^{19}$ observed that thermolysis of $\mathbf{8}$ in
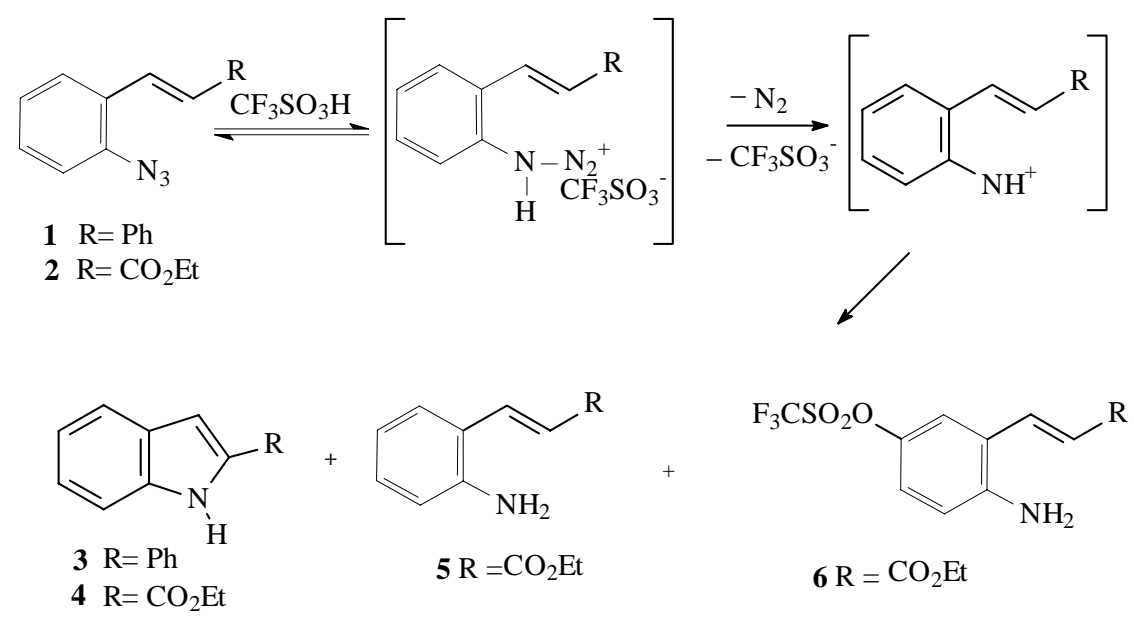

Scheme 1. 
cumene gave 2-phenyl- $1 H$-indole 3 in only $18 \%$ yield and an intractable tar, we repeated the thermal decomposition of azide $\mathbf{8}$ in xylene reflux and we obtained the same results. In order to explain the isolation of $\mathbf{3}$ Smith explained that when the phenyl and $o$-azidophenyl groups are cis, "there is steric interference with rotation of the $o$-nitrenophenyl group, making it difficult for it to engage the $\beta$ carbon. As a result, there is time for intersystem crossing to the triplet nitrene to take place, and formation of the observed tars results"19. By comparison, the decomposition of $c i s$-o-azidostilbene in acidic medium only gave $5 \mathrm{H}$ dibenzo[b,f]azepine in reasonable yield in our experiments.

Treatment of 2-(2-phenylethyl)phenylazide $9^{21}$ with triflic acid in dichloromethane gave an intractable dark material. However, with $\mathrm{AlCl}_{3}$ we isolated 10,11-dihydro-5H-dibenz[b,f]azepine 11, mp 107-108 ${ }^{\circ} \mathrm{C}^{22}$, in $20 \%$ yield, ortho-aminodihydrostilbene $\mathbf{1 3}$ in $12 \%$ yield $^{23}$ and 2'-amino-5'-dichlorodihydrostilbene 14 in low yield (detected in the mass spectrum). The geometry of $\mathbf{9}$ is not as favorable for intramolecular cyclization as the other two preceding examples and gave $\mathbf{1 1}$ in low yield. This less favorable geometry for cyclization leads the intermediate nitrenium ion to abstract hydrogen (via triplet species) forming 13 (together with tarry polymers) and to be intermolecularly intercepted by chloride ion giving 14 . Thermal decomposition of $\mathbf{9}$ in xylene reflux also gave an intractable tar. Tomioka et al. studied the photolysis of the azide of 9 in cyclohexane that afforded 2-phenyl- $1 H$-indoline exclusively in low yield ${ }^{24}$.

The decomposition of phenyl 2-azidobenzoate 15 (obtained from phenyl 2-aminobenzoate ${ }^{25}$ ) with triflic acid was slow when compared with the above examples and the only isolable compound was phenyl 2-amino-5-trifluoromethanesulfonylbenzoate $\mathbf{1 6}$ in $25 \%$ yield. With TFA under the same conditions most of the starting azide was recovered. Using $\mathrm{AlCl}_{3}$, two compounds were isolated: phenyl 2-amino-5-chlorobenzoate $\mathbf{1 7}, \mathrm{mp} \mathrm{87-88}{ }^{\circ} \mathrm{C}$, and phenyl 2-amino-3-chlorobenzoate $\mathbf{1 8}$, mp $114-115{ }^{\circ} \mathrm{C}$, in

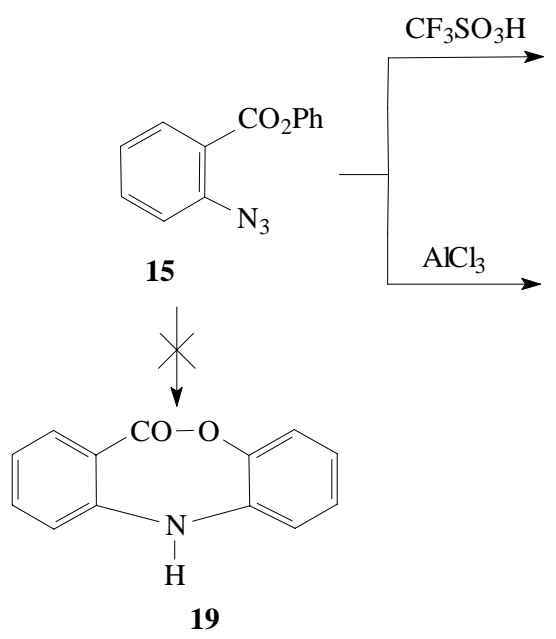

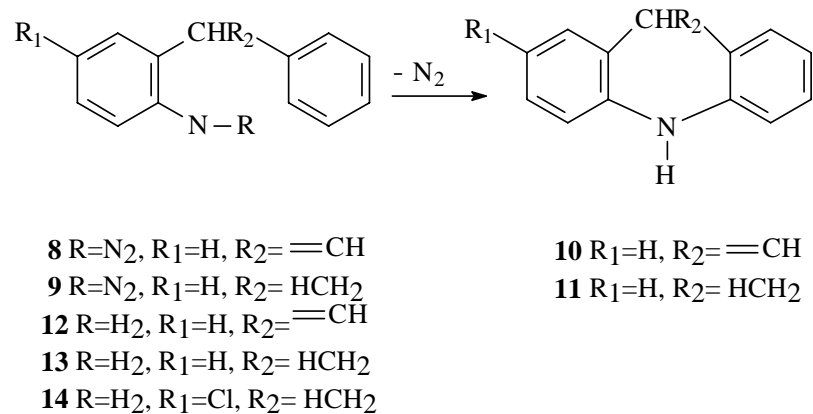

$26 \%$ and $14 \%$ yield, respectively. The nitrenium ion intermediate rather than cyclize to the dibenzoxazepine $1^{20}$ was para and ortho intercepted by the chloride or triflate ions. Decomposition of $\mathbf{1 5}$ in solution (thermolysis) and pyrolysis in the vapour fase gave only tarry materials. Using the technique of spray pyrolysis, Meth-Cohn et. al. decomposed 2-azidobenzoate $\mathbf{1 5}$ at temperatures above $380{ }^{\circ} \mathrm{C}$ giving a cyclized intermediate that lost $\mathrm{CO}_{2}$ and after rearrangement gave a carbazole in $53 \%$ yield $^{26}$.

We observed that with TFA the yields of the cyclized compounds are identical or greater than those with TFSA. A possible explanation is based on the rationalization proposed by Okamoto for the acid-based catalysed reaction of $\mathrm{N}$-arylhydroxylamines with the same acids that we have used. In TFA, the reaction center is the nitrogen atom and intramolecular nucleophilic attack probably proceeds at the nitrogen atom with some anilenium character ${ }^{27}$. In TFSA, Okamoto proposed a very reactive dicationic intermediate, the imine-benzenium ion, which takes part in the reaction and can be intercepted by a nucleophile at the ring. Using the same rationalization, one can propose a different behavior between TFA and TFSA for the acid decomposition of azides. We observed nucleophilic attack of the weak counter-ion at the ring only for the strong TFSA $\left(H_{o}=\right.$ $-14)^{28}$ catalyzed reaction (Scheme 2 , path b), while with<smiles>Nc1ccc(OS(=O)(F)(F)F)cc1C(=O)Oc1ccccc1</smiles><smiles>Nc1ccc(Cl)cc1C(=O)Oc1ccccc1</smiles>
17 
TFA, the cyclized product at the nitrogen was always formed with superior yields than those with TFSA, and no trifluoroacetate substituted product was formed (path a). Recently McClelland also proposed that a nitrenium ion accepts a proton to form an aniline dication $\left({ }^{1} \mathrm{ArNH}^{+} \rightarrow\right.$ $\mathrm{ArNH}_{2}{ }^{2+}$ ) which is better regarded as a 6-iminocyclohexadienyl carbocation ${ }^{29}$.

In conclusion, ortho-arylazides decompose in Lewis acids and strong protonic acids to give nitrenium ion intermediates which by an intramolecular electrophilic attack upon an ortho-aromatic nucleus regiospecificly form fiveand seven-membered nitrogen rings. It is not possible to predict a priori which acid will give cyclic products since it depends on the substituents of the aromatic starting material. When the geometry is favorable, the nitrenium ion is very efficient for the formation of a cyclized product and in this case the less acidic TFA gives a better yield than TFSA. Considering that the nitrenium ion is a very reactive species, an unfavorable geometry leads the intermediate to be intercepted by any nucleophilic species present in the reaction medium and even a weak nucleophile like trifluoromethanesulfonate ion can react. To avoid this intermolecular reaction, we propose that it is necessary to use a less acidic medium or to block the para and ortho positions in relation to the azide to allow the intramolecular electrophilic attack of the nitrenium ion upon an ortho-aromatic nucleus; further studies are in course to prove this assertion. Another possible pathway is via the initial singlet nitrenium ion with an extended lifetime which is transformed into a triplet nitrenium ion that may abstract hydrogen atoms ${ }^{30}$ from the medium to produce amines or tarry polymers ${ }^{9 c}$. Thermal decomposition of the same azides gave compara- ble results in some cases and better or worse than acid decomposition in other cases. This is not unexpected since different intermediates should be involved, nitrenium ion or nitrenium-like ion in the acid medium and nitrene species in the thermolysis.

\section{Experimental}

Chemicals were purchased from Aldrich Chemical Co. or prepared following literature procedures ${ }^{3}$. Melting points were obtained on a Fisher-Johns melting point apparatus and are uncorrected. Infrared spectra were taken on a Jasco A-202 spectrophotometer. The ${ }^{1} \mathrm{H}-\mathrm{NMR}$ spectra were recorded with a Bruker AW-80 spectrometer using tetramethylsilane as an internal standard. Mass spectra were obtained on a Varian Mat 311 A instrument at $70 \mathrm{eV}$ using a direct insertion probe. Preparative thick layer chromatography was carried out on plates coated with silica gel PF 254 (Merck) and column chromatography was run on silica gel 60 (Merck).

\section{General procedure for azide decompositions with tri- fluoroacetic or trifluoromethanesulfonic acids}

Trifluoromethanesulfonic acid (or trifluoroacetic acid) $(1.2 \mathrm{mmol})^{31}$ was added dropwise to a solution of the azide (1 mmol) in dichloromethane $(10 \mathrm{~mL})$ in a water-ice bath under nitrogen atmosphere and magnetic stirring. After the nitrogen evolution ceased, the reaction was neutralized with saturated solution of sodium bicarbonate, extracted with dichloromethane, dried with magnesium sulfate and the solvent evaporated. The crude residue was chromatographed on preparative plates using silica gel.

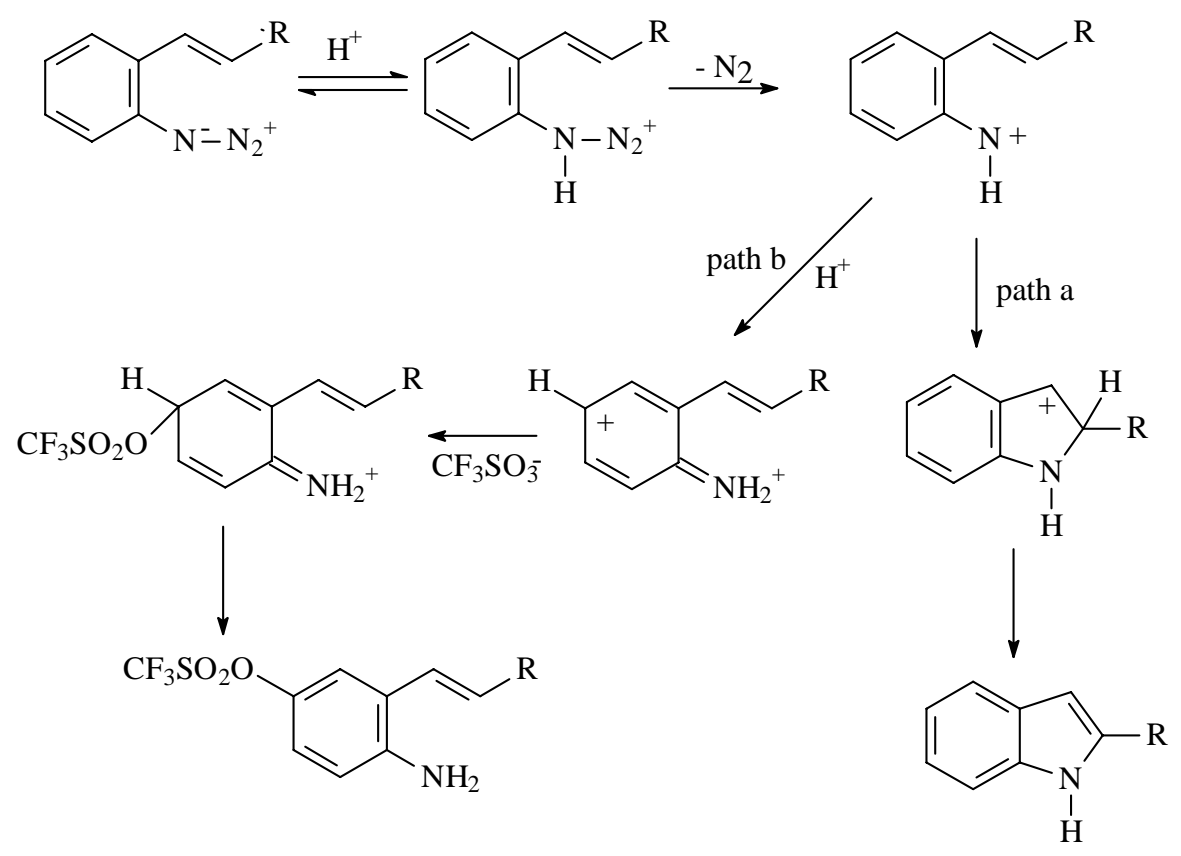

Scheme 2. 
General procedure for azide decompositions with aluminum chloride

Anhydrous dichloromethane $(10 \mathrm{~mL})$ was added to anhydrous aluminum chloride $(1.2 \mathrm{mmol})$ and the appropriate azide $(1 \mathrm{mmol})$ was added dropwise with stirring. After the evolution of nitrogen gas ceased, aqueous sodium hydroxide solution (10\%) was added and extracted with dichloromethane, dried over anhydrous magnesium sulfate and the solvent evaporated. The crude residue was chromatographed on preparative silica gel plate.

\section{Ethyl (E)-3-(2-azidophenyl)propenoate 2}

The ethyl (E)-3-(2-amino phenyl)propenoate 5 (0.955g, $0.5 \mathrm{mmol}$, prepared by reduction of ethyl 2-nitrocinnamate ${ }^{32}$ was dissolved in acetic acid $(15 \mathrm{~mL})$ and hydrochloric acid $(2 \mathrm{~mL})$, cooled to $0{ }^{\circ} \mathrm{C}$ and treated with a solution of sodium nitrite $(0.42 \mathrm{~g}, 0.6 \mathrm{mmol})$ in water $(2$ $\mathrm{mL})$. After the mixture had been stirred for a further $1 \mathrm{~h}$ at $0{ }^{\circ} \mathrm{C}$, a solution of sodium azide $(0.4 \mathrm{~g}, 6 \mathrm{mmol})$ in water $(2 \mathrm{~mL})$ was added. The mixture was stirred for $1 \mathrm{~h}$ and then neutralized with a saturated solution of sodium bicarbonate, extracted with dichloromethane ( $3 \times 60 \mathrm{~mL})$, dried with anhydrous magnesium sulfate, filtered and the solvent evaporated to give an oil. This oil was chromatographed $\left(\mathrm{SiO}_{2}\right.$, dichloromethane-hexane) to afford a solid that was recrystallized from hexane in the refrigerator to give the azide $2(0.75 \mathrm{~g}, 70 \%)$, m.p. $33-34{ }^{\circ} \mathrm{C}$ : IR (KBr) 2120, 1700, $16221510,1460 \mathrm{~cm}^{-1}$; MS (70 eV) 217( $\left.\mathrm{M}^{+}\right), 189 \mathrm{~m} / \mathrm{z}$.

Anal. Calcd. For $\mathrm{C}_{11} \mathrm{H}_{11} \mathrm{~N}_{3} \mathrm{O}_{2}$ : C, 60.82; H, 5.11; N, 19.34. Found: C, 60.77; H, 5.13; N, 19.34.

\section{Thermolysis of (E)-3-(2-azidophenyl)propenoate 2}

A solution of $2(0.217 \mathrm{~g}, 1 \mathrm{mmol})$ in xylene $(5 \mathrm{~mL})$ was refluxed for $18 \mathrm{~h}$ under argon. After evaporation of the solvent the residue was recrystallized from ethanol to give ethyl $1 H$-indole-2-carboxylate $(0.189 \mathrm{~g}, 75 \%)$ m.p. 124$125{ }^{\circ} \mathrm{C}$ (lit. $\left.{ }^{14} 124-125{ }^{\circ} \mathrm{C}\right)$, IR (KBr): 3226, 1681, 1527, $1383,1342,1316,1250,1205,822,772,756$; 1H NMR $\left(\mathrm{CDCl}_{3}\right) 1.40(3 \mathrm{H}, \mathrm{t}, \mathrm{J}=9 \mathrm{~Hz}), 4.42(2 \mathrm{H}, \mathrm{q}, \mathrm{J}=9 \mathrm{~Hz}), 7.0-7.8$ (5H, m), 9.58 (1H, broad); MS m/z (\%) $189\left(\mathrm{M}^{+}, 47\right), 144$ (21), 143 (100), 115 (35), 89 (23).

\section{Ethyl (E)-3-(2-amino-3-trifluoromethanesulfon-} atephenyl)propenoate 6

Yellow solid m.p. $86-87{ }^{\circ} \mathrm{C}$, IR(KBr): 3480, 3390, $1700 \mathrm{~cm}^{-1}$; 1H-NMR $\left(\mathrm{CDCl}_{3}\right): 1.32(3 \mathrm{H}, \mathrm{t}, \mathrm{J}=6 \mathrm{~Hz}), 4.08$ $\left(2 \mathrm{H}\right.$, broad, $\left.-\mathrm{NH}_{2}\right), 4.27(2 \mathrm{H}, \mathrm{d}, \mathrm{J}=6 \mathrm{~Hz}), 6.30(1 \mathrm{H}, \mathrm{d}, \mathrm{J}=$ $16 \mathrm{~Hz}), 6.65(1 \mathrm{H}, \mathrm{d}, \mathrm{J}=8 \mathrm{~Hz}), 7.03(1 \mathrm{H}, \mathrm{dd}, \mathrm{J}=8$ and 2 $\mathrm{Hz}), 7.20(1 \mathrm{H}, \mathrm{d}, \mathrm{J}=2 \mathrm{~Hz}), 7.70(1 \mathrm{H}, \mathrm{d}, \mathrm{J}=16 \mathrm{~Hz}) ; \mathrm{MS} \mathrm{m} / \mathrm{z}$ (\%) 339 (43), 294 (12), 206 (100), 160 (58), 146 (27), 131 (30), 118 (26), 104 (24).
Phenyl 2-amino-5-(trifluoromethanesulfonyloxy)benzoate 16

Oil, IR (film): 3500, 3400, 1710, 1625, 1600, 1498, 1425, 1290, 1270, 1270, 1230, 1200, 1146, 745, 705; ${ }^{1} \mathrm{H}-\mathrm{NMR}\left(\mathrm{CDCl}_{3}\right) 6.05$ (2H, broad), $6.65(1 \mathrm{H}, \mathrm{d}, \mathrm{J}=8.5$ $\mathrm{Hz}), 7.13-7.35$ (5H, m), $7.41(1 \mathrm{H}, \mathrm{dd}, \mathrm{J}=2 \mathrm{~Hz}$ and $9 \mathrm{~Hz})$, $7.83(1 \mathrm{H}, \mathrm{d}, \mathrm{J}=2 \mathrm{~Hz}) ; \mathrm{MS} \mathrm{m} / \mathrm{z}(\%) 361\left(\mathrm{M}^{+}, 18\right), 267$ (41), 228 (15), 214 (38), 120 (35), 107 (15), 72 (38), 59 (45), 45 (100).

\section{Phenyl 2-amino-3-chlorobenzoate 17}

White solid m.p. $87-88^{\circ} \mathrm{C}$, IR (KBr): $3350,3340,1700$, 1605,1580, 1440, 1300, 1240, $1196 \mathrm{~cm}^{-1}$; ${ }^{1} \mathrm{H}-\mathrm{NMR}$ $\left(\mathrm{CDCl}_{3}\right): 5.42(2 \mathrm{H}$, broad $) 6.62(1 \mathrm{H}, \mathrm{d}, \mathrm{J}=8 \mathrm{~Hz}), 7.15-7.36$ $(5 \mathrm{H}, \mathrm{m}), 7.50(1 \mathrm{H}, \mathrm{dd}, \mathrm{J}=3 \mathrm{~Hz}$ and $\mathrm{J}=8 \mathrm{~Hz}), 7.83(1 \mathrm{H}, \mathrm{d}$, $\mathrm{J}=3 \mathrm{~Hz}$ ); MS m/z (\%) 249 (24), 247 (72), 155 (97), 153 (100), 128 (5), 126 (20), 90 (45).

\section{Phenyl 2-amino-5-chlorobenzoate 18}

White solid (m.p. 114-115 ${ }^{\circ} \mathrm{C}$ ), IR (KBr): 3495, 3400, 1690, 100, 1580, 1485, 1285, 1220, $1190 \mathrm{~cm}^{-1}$; ${ }^{1} \mathrm{H}-\mathrm{NMR}$ $\left(\mathrm{CDCl}_{3}\right): 5.60$ (2H, broad), 7.02(1H, t, J = 8 Hz), 7.16-7.33 $(5 \mathrm{H}, \mathrm{m}), 7.53(1 \mathrm{H}, \mathrm{dd}, \mathrm{J}=2 \mathrm{~Hz}$ and $\mathrm{J}=8 \mathrm{~Hz}), 7.95(1 \mathrm{H}$, dd, $\mathrm{H}=2 \mathrm{~Hz}$ and $8 \mathrm{~Hz}$ ); MS m/z (\%) 249 (12), 247 (50), 213, 155 (30), 153 (100), 126 (15).

\section{Acknowledgments}

The authors thank FAPESP (process 85/3256-4) for financial support.

\section{References}

1. (a) Robbins, R.J.; Yang, L.L.-N.; Anderson, G.B.; Falvey, D.E. J. Am. Chem. Soc. 1995, 117, 6544. (b) McCelland R.A.; Kahley, M.J.; Davidse, P.A. J. Phys. Org. Chem. 1996, 9, 355. (c) Moran, R.J.; Falvey, D.E. J. Am. Chem. Soc.1996, 118, 8965. (d) Moran, R.J.; Cramer, C.; Falvey, D.E. J. Org. Chem. 1997, 62, 2742.

2. (a) Turesky, R.; Markovic, J. J. Chem. Res. Toxicol. 1994, 7, 752. (b) Kadlubar, F.F. In DNA Adducts Identification and Significance; Hemminki, K.; Dipple, A.; Shuker, D.E.G.; Kaldlubar, F.F.; Segerbäck, D.; Bartsch, H., Eds.; University Press: Oxford, UK, 1994; p. 199-216.

3. Schut, H.A.; Castongauy, A. Drug Metab. Rev. 1984, $15,753$.

4. Novak, M.; Kennedy, S.A. J. Am. Chem. Soc. 1995, 117, 575.

5. Davidse, P.A.; Kahley, M.J.; McClelland, R.A. Novak, M. J. Am. Chem. Soc. 1994, 116, 4513.

6. (a) Abramovitch, R. A.; Jeyaraman, R. Azides and Nitrenes; Scriven, E. F. V., Ed.; Academic Press: Orlando, 1984; ch. 6, p. 297-357. (b) Abramovitch, R. 
A.; Barton, D. H. R.; Finet, J. -P. Tetrahedron 1988, 44, 3039. (c) For an excellent review on nitrenium ions see: Ford, G.; Herman, P.S. J. Chem. Soc., Perkin Trans 2 1991, 607.

7. (a) Abramovitch, R.A.; Cooper, M.; Iyer, R.; Jeyaraman, R.; Rodrigues, J.A.R. J. Org. Chem. 1982, 47, 4819. (b) Abramovitch, R.A.; Jeyaraman, R.; Yannakopoulou, K. J. Chem. Soc., Chem. Commun. 1985, 1107. (c) Abramovitch, R.A.; Hawi, A.; Rodrigues, J.A.R.; Trombeta, T. Ibid. 1986, 284. (d) de Sousa, J. D.F.; Rodrigues, J.A.R; Abramovitch, R.A. J. Am. Chem. Soc. 1994, 116, 9745. (e) Abramovitch, R.A.; Cooper, M.; Jeyaraman, R.; Rusek, G. Tetrahedron Lett. 1986, 27, 3705.

8. (a) Zanirato, P. J. Chem. Soc., Chem. Commun. 1983, 1065. (b) Spagnolo, P.; Zanirato, P. J. Chem. Soc., Perkin Trans 1, 1988, 2615. (c) Stadlbauer, W.; Pfaffenschlager, A.; Kappe, T. Synthesis 1989, 781. (d) Abramovitch, R.A.; Chinnasamy, P.; Evetrz, K.; Huttner, G. J. Chem. Soc., Chem. Commun. 1989, 3.

9. (a) Takeuchi, H.; Takano, K. J. Chem. Soc., Perkin Trans. 1 1986, 611. (b) Takeuchi, H.; Shiobara, Y.; Kawamoto, H.; Koyama, K. J. Chem. Soc., Perkin Trans. 1 1990, 321. (c) Takeuchi, H.; Maeda, M.; Mitani, M.; Koyama, K. J. Chem. Soc., Perkin Trans 1, 1987, 57.

10. Takeuchi H.; Maeda, M.; Mitani, M; Koyama, K. J. Chem. Soc., Perkin Trans. 1 1991, 57.

11. Olah, G.A.; Ramaiah, P.; Wang, Q.; Prakash, G.K.S. J. Org. Chem. 1993, 58, 6900.

12. Sundberg, R.J.; Russel, H. F.; Ligon, W. V.; Lin, L.-S. J. Org. Chem. 1972, 37, 719

13. Taylor, T.W.; Hobson, P.M. J. Chem. Soc. 1936, 181.

14. Gränacher, C.; Mahal, A.; Gerö, M. Helv. Chim. Acta 1924, 7, 579.

15. Hermtsberger, H.; Knittel, D.; Weidman, H. Monatsh. Chem. 1969, 100, 1599.

16. Moody, C.J.; Rees, C.W.; Rodrigues, J.A.R.; Tsoi, S.C. J. Chem. Research (S) 1985, 238.

17. Hermtsberger, H.; Knittel, D.; Weidman, H. Monatsh. Chem. 1970, 101, 161.
18. (a) Rugli, P.; Staub, S. Helv. Chim. Acta 1937, $20,37$. (b) Detar, D.F.; Chu, Y.M. J. Am. Chem. Soc. 1954, 76, 1685.

19. Smith, P.A.S.; Rowe, C.D.; Hansen, D.W. Tetrahedron Lett. 1983, 24, 5169.

20. Sadtler Standard Spectra, IR spectrum 25522, Sadtler Research Laboratories, Inc., 1972.

21. 1-Azido-2-(2-phenylethyl)benzene 9 was prepared by hydrogenation of 1-nitro-2-(2-phenylethyl)benzene to the corresponding amine that was transformed to azide by the diazotation method. The IR and NMR data were identical with those reported by Tomioka, Ref. 24 .

22. Sadtler Standard Spectra, IR spectrum 85522, Sadtler Research Laboratories, Inc., 1972.

23. Mann, F.G.; Stewart, F.H.C. J. Chem. Soc. 1954, 4127.

24. Shigueru, M.; Yoshidome, R.; Satoh, Y.; Kato, N.; Tomioka, H. J. Org. Chem. 1995, 60, 1428.

25. Gurien, H.; Malarek, D.H.; Rachlin, A.I. J. Heterocycl. Chem. 1966, 3, 527.

26. Clancy, M.G.; Hesabi, M.M.; Meth-Cohn, O. J. Chem. Soc., Perkin Trans 1 1984, 429.

27. (a) Ohta, T.; Machida R.; Takeda, K.; Endo, Y.; Shudo, K.; Okamoto, T. J. Am. Chem. Soc. 1980, 102, 6385. (b) K. Shudo, Ohta, T.; Okamoto, T. J. Am. Chem. Soc. 1981, 103, 645.

28. Grondin, J.; Sagres, R.; Cornmeyras, A. Bull. Soc. Chim. Fr. 1976, 1779.

29. (a) McClelland, R.A.; Kahley, M.; Davise, P.A.; Hadzialic, G. J. Am. Chem. Soc. 1996, 118, 4794. (b) Gadosy, T.A.; McClelland, R.A. J. Am. Chem. Soc., 1999, $121,1459$.

30. Gassman, P.S.; Cryberg, R.L. J. Am. Chem. Soc. 1969, $91,5157$.

31. The use of sub-stoichiometric quantities of the acid gave poor yield of products with some starting material.

32. Sudborough, J.J.; Lloyd, L.L. J. Chem. Soc. 1898, 73, 85.

Received: February 26, 1999

FAPESP helped in meeting the publication costs of this article 